Maurer School of Law: Indiana University

Digital Repository@Maurer Law

Indiana Law Journal

Volume 64 | Issue 3

Article 7

Summer 1989

\title{
Law, Lawyers, and Legal Practice in Silicon Valley: A Preliminary Report
}

Lawrence M. Friedman

Stanford University

Robert W. Gordon

Stanford University

Sophie Pirie

Stanford University

Edwin Whatley

Stanford Law School

Follow this and additional works at: https://www.repository.law.indiana.edu/ilj

Part of the Internet Law Commons, and the Legal Profession Commons

\section{Recommended Citation}

Friedman, Lawrence M.; Gordon, Robert W.; Pirie, Sophie; and Whatley, Edwin (1989) "Law, Lawyers, and Legal Practice in Silicon Valley: A Preliminary Report," Indiana Law Journal: Vol. 64 : Iss. 3 , Article 7. Available at: https://www.repository.law.indiana.edu/ilj/vol64/iss3/7

This Symposium is brought to you for free and open access by the Law School Journals at Digital Repository @ Maurer Law. It has been accepted for inclusion in Indiana Law Journal by an authorized editor of Digital Repository @ Maurer Law. For more information, please contact rvaughan@indiana.edu.

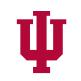

JEROME HALL LAW LIBRARY

INDIANA UNIVERSITY

Maurer School of Law
Blooming ton 


\title{
Law, Lawyers, and Legal Practice in Silicon Valley: A Preliminary Report
}

\author{
LAWrence M. Friedman, Robert W. Gordon, \\ SophIE PIRIE, EdWIN WhatLeY*
}

What do lawyers contribute to technological change and economic development? Much popular opinion assumes that the contribution is mostly negative, that the vast amounts of legal time billed to corporate enterprise ( $\$ 38$ billion worth annually, according to a recent estimate) ${ }^{1}$ are the pathological symptoms of an over-regulated, excessively litigious culture that diverts resources from productivity and innovation into wasteful paperpushing. ${ }^{2}$ Other, more sanguine observers-usually lawyers-argue to the contrary that legal services are valuable, even indispensable parts of the infrastructure that support the efficiency of transactions, even if their value is not always appreciated by clients or the general public. ${ }^{3}$ The debate has been chiefly at the level of assertion, because there has been so little serious research since James Willard Hurst's monumental study in 1964 of the ways in which lawmakers and lawyers designed and operated the legal-institutional frameworks for the growth and organization of the lumber industry in nineteenth century Wisconsin. ${ }^{4}$ Studies of the "legal profession" tend to focus on the organization, entry policies, education and ethics of the bar. Although some excellent work has recently appeared on the social structure of the bar and the internal organization and cultures of law firms, ${ }^{5}$ there is still almost no scholarly research into lawyers' actual work tasks. So before approaching the grand questions of how lawyers facilitate or parasitically feed off economic growth, we need to have reliable pictures of their practices, of the ordinary jobs they do for their business clients.

* Lawrence M. Friedman, Marion Rice Kirwood Professor of Law, Stanford University; Robert W. Gordon, Professor of Law, Stanford University; Sophie H. Pirie, Stanford Law School '87, Member of the California Bar; Edwin Whatley, second year student, Stanford Law School.

1. Flaharty, The $\$ 38$ Billion Legal Market, Nat'I L.J., Jan. 30, 1984, at 2, 52, col. 2.

2. See, e.g., R. Reich, The NeXT AMerican FrontIER (1983).

3. Gilson, Value Creation by Business Lawyers: Legal Skills and Asset Pricing, 94 YAlE L.J. 239 (1984).

4. J. HURST, LAW AND ECONOMIC GROWTH: THE LEGAI HISTORY OF THE LURBER INDUSTRY IN WisconsIN, 1836-1915 (1964). Even Hurst's book, though it describes in minute detail the network of legal rules and institutions regulating the timber trade, says little about the legal agents who transmitted the rules and operated the institutions through advice to and actions taken on behalf of clients. Hurst developed a more explicit view of lawyers as facilitators of economic change in THE GROWTH of AMERICAN LAW: THE LAWMAKERS 333-66 (1950).

5. See, e.g., J. Heinz \& E. Laumann, Chicago Lawyers: The Soclai Structure of the Bar (1982); R. Nelson, Partners with Power (1988); M. Galanter \& T. Palay, The TRANSFORMATION OF THE LARGE LAW FIRM (American Bar Foundation conference paper, 1987). 
Inspired by the example of Hurst's work, the authors have begun to study the lawyers who work in Palo Alto, California-the legal hub of the computer products industries of the Silicon Valley. As a subject of study, the Silicon Valley is nearly ideal. It has a dense concentration of lawyers, and a dense concentration of new industry. The lawyers claim that their role in the Valley's boom has been extremely influential. The industry and the legal practice that has grown up around it are both young; their entire histories are within the grasp of living memories. The explosive pace of growth gives us the chance to watch basic changes in form unfold even as the study progresses. This brief paper describes, in general terms, some of the observations and hypotheses arrived at after preliminary work on the project.

\section{The History of Lawyers in Silicon Valley}

Even when Silicon Valley was still largely agricultural, more famous for prunes than for computers, the small city of Palo Alto was home to a fair number of lawyers. Most of them, however, were commuters, who traveled by train to offices in San Francisco. The few with an authentically local practice did a typical small town law office business: writing wills, incorporating small businesses, documenting real estate deals, defending petty criminals, and the like. Minor-league though it may have been, Palo Alto was a thriving legal center compared to its neighbors. In the 1920 's, when Sunnyvale, Menlo Park, and Mountain View each had one or two lawyers, and two county seats, San Jose and Redwood City had about twenty lawyers each. Tiny Palo Alto had fourteen. This number grew to 50 lawyers by the 1950 's, then to 250 in the 1960's. Today, Palo Alto, with a population under 60,000 , has over 1000 lawyers practicing within the city limitsperhaps the highest ratio of lawyers to population anywhere in the United States outside Manhattan and perhaps Washington, D.C. ${ }^{6}$

What initially drew these lawyers to Palo Alto, at a time when it seemed so unlikely a starting place for careers? There is no single answer. Each lawyer whom we interviewed had his own special story. Some had met Palo Altans in Eastern law schools; some wanted a smaller, less stuffy practice than San Francisco offered. The only common theme in their stories is the physical beauty of Palo Alto, its weather, and its attractiveness as a place to live and raise children. Of course, Palo Alto was not the only small town in an attractive location close to a major university and a cosmopolitan city. But for whatever reasons, these lawyers defined Palo Alto as a distinctive and desirable community; this shared sense of the place has

6. Compare listings for Palo Alto with those of Manhattan and Washington, D.C. in MARTINDALE-HudBbell LAW DirEctory (1989). 
helped to make it a distinctive legal community as well, which Palo Alto's boosters praise over Bay Area rivals San Francisco and San Jose. When Palo Alto lawyers make recruiting pilgrimages across the country, they still play up the Valley's lifestyle, as if the population, housing and traffic booms, and the sharp intensification of worklife-the seventy- and eightyhour week-around the high-tech industries, had never occurred.

In the 1950's, there were already some lawyers in the Palo Alto bar who had begun their careers on the East Coast, or in the industrial heartland, or in San Francisco. Quite likely, no explosion of lawyering in Palo Alto could have occurred without lawyers who had a strong professional background and useful skills. But it was not at all inevitable that local lawyers would be able to take hold and provide services for new industry. Local lawyers, after all, had chosen (for whatever reasons) to practice in the backwaters of Palo Alto, rather than in the great centers like San Francisco or New York. The experienced firms of San Francisco were not far away. Clients could ride the Southern Pacific to "the City" just as the lawyers did. Why use a small town lawyer when you needed infusions of capital or big-scale advice on corporate structure?

\section{Legal Services ReQuired by New Businesses}

Before we suggest some reasons why a flourishing local bar emerged to handle the legal business of high-tech industries, it might be useful to specify more generally the types of legal services that new industries ordinarily seem to need. Historical experience suggests the following loose sketch that describes the evolving demand for legal skills.

In the start-up phase, small businesses, especially those run by scientists and engineers without business experience, need access to elementary advice about such matters as record-keeping for tax and accounting purposes, and such basic legal services as the drafting of partnership agreements and secured financing documents. Lawyers in this society have often also been used as repositories of general knowledge of business practices, for advice that the client can neither generate internally nor afford to buy from other outside sources. A business must also hire and pay lawyers for services only they can legally perform. Thus, the added cost of general business advice is low, especially when lawyers can draw upon experience with similar clients who have faced similar problems. Lawyers in this phase also function as all-purpose intermediaries, as links between entrepreneurs and financial sources, as well as between business and government agencies at all levels. ${ }^{7}$ When giant enterprises formed in the late nineteenth and early twentieth centuries, lawyers made key links between management of railroad and

7. J. Hurst, The Growth of AMerican LAw: The LawMakers 295-305 (1950). 
manufacturing corporations, on the one hand, and, on the other, the investment banking houses of Wall Street and Europe, which underwrote the vast consolidations of 1898-1906. Lawyers designed the risk-reward-andsecurity structures to attract different types of investment and often acted as salesmen of new issues of securities. ${ }^{8}$

The maturing of an enterprise, in the regulatory environments that have been constructed in this country starting with the Progressive movements and New Deal, has called for a different, and much more specialized, range of legal services. Companies usually identify the stage at which their consumption needs for lawyers sharply changes as the decision to "go public." The legal job of registering the company's stock issues under the federal and state securities laws calls for disclosure of company information and preparation of incredibly detailed forms, specialists in securities law, a staff of paralegals and secretaries to do the routine state "Blue Sky" registrations, and, perhaps most important, enough experience with similar transactions to have produced files full of forms to copy. Mistakes in these transactions can be very costly, exposing companies to civil damage actions and heavy fines.

The decision to go public usually also entails changes in management and organization that call for other new legal tasks: design of executive compensation plans, employee pension plans, tax plans, and the like. City law firms with divisions of specialists and established reputations in corporate work have an obvious edge in their ability to attract such business. At this stage, it is not efficient for these companies to hire an internal legal staff that can handle "going public." But neither can the companies continue to rely on solo practitioners and small partnerships for this complicated, specialized work. At this stage-which many industries in Silicon Valley have reached-mid-sized companies tend to use mid-sized firms, although the biggest downtown firms, who are afraid of losing business to in-house counsel, have tried to move in on the mid-sized market as well.9

If the company continues to prosper and grow, and avoids the need for the ghoulish services of bankruptcy specialists (another booming Silicon Valley legal field), its legal needs may change yet again. It may reach a third stage in which the company may want to take over or merge with other companies, or, conversely, defend itself against takeover attempts. It

8. See generally A. Chandler, The Vistble Hand: The Managerial Revolution in American Bustaness 122-44 (1977); A. Dean, William Nelson Cromwell, 1854-1948: AN american Pioneer in Corporation, Comparative and International law (1957); Law and the Formation of the Big ENterprises in the 19TH aND EARLy 20TH Centuries (N. Horn \& J. Kocka eds. 1979); R. Swaine, The Cravath Firm and its Predecessors, 1819-1948 (1946-48).

9. On this last point, see R. Csaplar, A Preliminary Study of the Macro-Economic Forces Moulding the Larage Business Law Firm 15, 18-19 (Harvard Law School Program on the Legal Profession working paper, 1984). 
may wish to acquire foreign subsidiaries, or to engage in joint ventures or arrangements to cross license its technology. It may need legal help with union recognition or collective bargaining negotiations (although unions have not gotten a firm foothold in the Valley so far). It will probably need antitrust advice. It is likely to be dealing constantly with regulatory authorities on health, safety, and environmental matters. It is likely to be embroiled in litigation to protect its intellectual property rights and market share. And finally, it may, through its trade association or on its own account, see itself as having a major stake in or entitled to a major influence over the formation of public policies regarding taxes, labor, intellectual property, tariffs, trade, and regulation..$^{10}$

For such needs as these, companies tend to adopt a two-tiered strategy. They are likely to bring an increasing amount of work in-house-not only the more routine legal work that they formerly contracted out to firms, but also the general business advising function. The company's generai counsel's office assumes the important function of deciding when to stay inside and when to contract outside, with whom, and on what terms; it also serves as the chief monitor of the outside work. ${ }^{11}$ House counsel will draw on outside legal and business counsel only for specialized and non-routine matters, and will spread such transactions-a new stock offering, a piece of litigation business, the job of designing an employee stock-option plan-around different outside firms rather than placing all their eggs in a single firm. The outside firms capable of such specialized work are usually either the very largest downtown metropolitan firms, who can muster large forces of specialized manpower at short notice to counter a takeover bid or an antitrust suit, or else smaller, super-specialized "boutique" firms. ${ }^{12}$.

\section{Legal Services and High Tech in SIIICON Valley}

How does this very general model of the phases of the evolution of corporate needs for legal services map onto the Silicon Valley experience? Many of the high-tech companies began as tiny outfits-twentieth century analogs to bakeries or dry cleaning shops. When they found themselves,

10. For historical examples of demands made by enterprises for these kinds of legal work, see A. Chandler, Pierre S. DuPont and the Making of the Modern Corporation (1971); A. Eichner, The Emergence of Oligopoly: Sugar Refining as a Case Study (1969); R. Hidy \& M. Hidy, Pioneering in Big Business, 1882-1911: The Standard OIl Company (1955); H. Passer, The Electrical Manufacturers, 1875-1900 (1953).

11. See A. Chayes \& A. Chayes, Corporate Counsel and the Control of the Corporate Legal Function (1986) (unpublished manuscript); R. Rosen, Lawyers in Corporate DecisionMaking (1984) (Ph.D. dissertation [Jurisprudence \& Social Policy] Univ. of California, Berkeley).

12. See Chayes \& Chayes, Corporate Counsel and the Elite Law Firm, 37 StAN. L. Rev. 277 (1985) (discussing the role of in-house counsel and its effects on law firms). 
often to their surprise, with revenues in the millions, they needed lawyers who could provide the same services, especially in fields like securities regulation, that big-city lawyers were providing large, established clients elsewhere. So naturally, in the early years of the high-tech boom, companies entering the second phase thought of going to San Francisco for legal services, rather than to local lawyers who had chosen to practice in the provincial backwaters of Palo Alto. The resulting division of labor between San Francisco and the Peninsula bar was, in the main, acceptable to Palo Alto lawyers. Most were solo practitioners, each with a mix of civil and criminal work. A few had banded together into loose associations, sharing common office space; a few had formed two-man partnerships, in which one partner concentrated on litigation, and the other on corporate work. Local lawyers tended to believe that only big firms, staffed with experts, could handle public offerings of stock. The accounting firms, which figure in any major financing, hesitated to let their clients use Peninsula lawyers: they too preferred legal opinions from brand name firms. ${ }^{13}$

Ultimately, two Peninsula lawyers-John Wilson and Leo Ware-decided, independently of each other, to take the plunge. They saw no reason why they could not cope with public offerings. After all, securities work is not the only form of practice that takes skill and experience. Ware and Wilson were general practitioners. They were used to learning new legal skills on short notice. They had stood on the sidelines while their clients went public. They had observed and felt ready to participate; they did not think of themselves as country bumpkins. And, significantly, they found some indulgent clients, guinea pigs willing to resist the "Go North" tradition.

Because [we] had been in big law firms . . . we did think that given an opportunity we could develop whatever expertise necessary .... [O]ur first client that wanted to go public, we didn't think about sending it out to somebody else. We took it public ourselves. When it became important to struggle with complicated tax matters, why we recruited people out of the NYU graduate tax program . . . . ${ }^{14}$

The crucial decision was far-reaching; but it was perhaps idiosyncratic. Other lawyers, who had equal stature in the legal community, and clients ready for large infusions of capital, chose not to join the bandwagon. Today, the firms of Wilson and Ware are the two biggest, most successful Silicon Valley firms. One contemporary of Wilson and Ware, who chose to stay put, is still a general practitioner, in a small, three lawyer office,

13. Our primary sources of information on the history of Silicon Valley practice are our transcribed interviews with Palo Alto lawyers, cited here simply as "Interview Material." Until the terms are clarified under which these lawyers' remarks may be made use of for publication, we will keep them anonymous. The authors have certified the accuracy of this material to the Indiana Law Journal.

14. This quotation and all those that follow are from our Interview Material. 
modern only in that the other two partners are women. This lawyer is not a failure; he has a thriving practice. After all, Silicon Valley is not just the location of a spectacular industrial boom. Real people live there, with real if mundane legal problems-people who marry and divorce, buy property and sell it, make out wills, and even die. Not everyone works for IBM or Apple or Genentech; and for those who do, these companies do not define all aspects of their existence. But the lawyers who "stayed behind" were nonetheless affected by the high-tech boom. It brought them work, simply by increasing the need for building permits, drafts of condominium agreements, and the incorporation of sushi bars and car washes. These lawyers were and are busy at their usual jobs-as pervasive facilitators in society. Their ranks have been swelled by a new generation of solos and small-firm lawyers, some of whom have deliberately turned their back on high-tech practice. These lawyers, almost totally neglected by scholarship and the media, are worth a closer look.

For present purposes, however, high-tech firms like Wilson, Sonsini, or Ware \& Friedenrich, are the more interesting story. As the high-tech clients grew in number and size, hired more employees, and increased their revenues, the law firms grew as well; they acquired more clients, hired more associates, and raised their fees. In one sense, they were merely riding the waves. Or did the firms help make the waves? Did they make the boom possible by clearing away legal obstacles, by finding and brokering the union of brains and money, and by structuring arrangements?

There is no way, as yet, to answer these questions. But the two opposing perspectives on practice are each important. They influence the way the lawyers perceive themselves, and perhaps they influence the practice as well. To understand law and lawyers in Silicon Valley, it is probably best, paradoxically, to accept both perspectives as reasonably accurate: Lawyers reacted to the high-tech boom, but they also helped to shape it. It is interesting to ask how they reacted, how they shaped events, and what effect their actions had on their rhetoric, their practice, and their social utility.

Some of the leading lawyers themselves, pressed to describe their contribution to the high-tech industries' growth, tend to stress those aspects of their practice roles and styles that in their view distinguish them from big downtown firms of corporate lawyers, especially in New York. They can offer their clients, they claim, service that business lawyers outside the hightech regions cannot offer: general business advice based on local industryspecific knowledge, access to local sources of venture-capital financing, a facilitative, or "engineering" approach to the client's problems, and, very notably, a style of law practice-informal, practical-result-oriented, flexible and innovative, keyed to high-trust business relations-that matches the business culture of Silicon Valley. Each of these types of service needs a little elaboration. 
General advice. Silicon Valley lawyers typically service the full range of legal needs of high-tech clients. These lawyers are highly specialized with regard to the type of client they serve, but not with regard to the kind of work they do for these clients. They can give "full-service" advice because they know the industry ${ }^{15}$ and don't have to be educated constantly in every new client's problems at the client's expense. A lawyer famous in the Valley chiefly as a licensing specialist, for example, says:

I would say, "I'm a high-tech company lawyer," and every word in that description is limiting. I represent the companies, not the investors, and I try to keep up in many areas of the law: securities, corporations law, tax law, copyright law, trade secret law, antitrust law, foreign trade, Export Administration Act. I try to read the legal periodicals, and stay current and give advice in all these areas as they affect local high-tech companies.

Access to Capital. In the start-up phase of the Silicon Valley companies, for example, local lawyers seem to have performed, as they still do, the classic functions of general business advising and financial intermediation. It may well be that one of their most important contributions has come from the fact that they knew all the venture capitalists personally and could set up lunches with them for their scientist and engineer clients.

Our clients needed money, so we would try to come up with ideas for this, and of course the client also had ideas. . . . [T] here weren't very many, but what resources there were for venture capital, we knew about. For example, one of our early clients was funded by DuPont and then DuPont decided to cut back and sold out to Laurence Rockefeller, so we did a deal with Laurence Rockefeller, so we knew Laurence Rockefeller's office. ... [W] got to know Tommy Davis and Art Rock a little bit, and then as the venture capital community grew, why we kind of grew with it.

Facilitative Law. The Silicon Valley lawyer not only works with engineers, he thinks of himself as a kind of engineer-a legal engineer. His job is not just counseling or advising on what the law is; his job is to solve problems: to take a principle, a task and "engineer" it legally, showing how it can be done, or be done best. It is not his job to say something can't be done, but to show how it can be done. In his view, the New York or Boston lawyer lacks this facility, this attitude, or has it to a lesser degree:

I think the most interesting legal problems are the ones where a client comes in with a new technology or a new problem and there is no form book to go and change the dates and names. You really have to stare

15. Opinion is divided among the lawyers interviewed about whether a background in hightechnology science or engineering is an asset in their practice. Predictably, those who have such a background think it helps a great deal; those without it say it doesn't much matter, except to help the lawyer establish rapport. Probably such training is useful for some types of legal work, irrelevant to others. 
at the ceiling and say, "Gee, if I were in this business, what would be the asset I would want to protect, and how would I commercialize it, and what would have to be the legal form of protection, and what would the documents have to look like, so that commerce wouldn't be impeded every time you wanted to make a sale?" . . .

[The clients] operate at high speed, expect your lawyers to operate at high speed. They are mostly engineers, and they approach problems that way. The protector, the person who prevents somebody from violating the law or saying something can't be done-our clients continually complain about lawyers who say no. They say, "OK, here's what we want accomplished. Here's the legal problem. What's the work-around?" That's literally the vocabulary they use, and they assume there's a legal barrier somewhere. They don't mean, "How do I violate the law?" but "How do I structure the deal, so I don't have that problem?" And I think in many cases lawyers are satisfied when they say you can't do what you propose to do, because it would violate the law. ... And here the clients expect you to take the next step and solve the problems.

Congruence of Legal and Business Styles. The claim that the legal style of Valley practitioners suits the clients' styles of doing business is one of the most intruiging, if also one of the hardest to pin down. We have been told by some local lawyers, for example, that the typical venture financing document is shorter than its New York City counterparts (such as the trust indentures that secure large-scale corporate debt). Its language is more general. It does not try to spell out contingency plans for every conceivable event that could go wrong, but assumes that the parties will be able to cooperate sufficiently to work out flexible adjustments to changing circumstances. Such deals have the "high-trust" or "relational" character that sociologists of law and business attribute to communities of traders or firms engaged in long-term ongoing relations. ${ }^{16}$ If these claims that Silicon Valley law practice differs from New York City and San Francisco practice are at all valid-at this stage the claims are plausible but unproven-it remains unclear how best to go about explaining the differences. Many of the features of local law practice seem exactly what one would expect, given the ideal-typical model of the evolution of corporate legal needs sketched above. General business advice, as previously remarked, is what relatively small-scale clients simple organizational structures and no efficiency drives to internalize the lawyer's type of expertise. Financial intermediation is a classic lawyers' contribution to start-up entrepreneurs. An "engineering" or

16. On the legal forms of continuing relations, see Macaulay, Non-Contractual Relations in Business: A Preliminary Study, 28 AM. Soc. REv. 55 (1963); Macneil, Relational Contract: What We Do and Do Not Know, 1985 Wis. L. REv. 483; on variations in contracting cultures (especially in Japan), see Dore, Goodwill and the Spirit of Market Capitalism, 34 BRIT. J. Soc. 459 (1983); on corporate debt contracts generally, see Bratton, The Interpretation of Contracts Governing Corporate Debt Relationships, 5 CARDozo L. REV. 371 (1984). 
facilitative style of advice also seems to be the dominant mode of the early phases.

In a market where there are many small, starting firms, a shake-out period arrives, sooner or later. Many businesses fail; others merge into larger units. In the consolidation phase, competition between units in the industry becomes fiercer; companies struggle to gain and hold territory. The focus shifts somewhat away from wealth creation forward to wealth conservation. The "engineer" lawyer may decline in value, to be replaced by the warrior-litigator, or the defensive planner. ${ }^{17}$ The relative informality of the legal practice in the Valley may thus reflect the needs of start-up ventures, and is therefore likely to fade over time, as enterprises mature. On the other hand, this style may effect the structure of the market for venture capital, which links capitalists and entrepreneurs in long-term relationships whose survival calls for a high degree of reciprocity, flexibility, and mutual trust. Or some of the differences in style may simply reflect differences in East and West coast corporate cultures (this theory could be tested by comparing the Valley to high-tech law in the Route 128 industries around Boston).

There is nothing determined or inevitable about the ideal-typical model of the evolution of law practice. Distinctive modes of practice in Silicon Valley, if real, may well survive into the mature phases of those industries and firms which are the lawyers' major clients. At the time of writing (October, 1988), however, there have been many signs that the big local firms are undergoing the kinds of strains of growth that are common elsewhere. As business clients expanded and became large enterprises, the law firms that had linked their futures with those clients expanded too; this brought with it severe shocks and tensions in the organization and cultures of the firms. Like firms in San Francisco and other cities, the major law firms of Palo Alto are bigger, more bureaucratic and more specialized. The largest firm has grown from seven partners and fifteen associates in 1980 to forty-one partners and eighty-eight associates in $1988 . .^{18}$ The major firms have demanded longer and longer working hours of their associates, and created severe dilemmas for associates-often, but not always, womenwho also want time for family life. Some associates-again, by no means all of them women-have dropped out (or allowed themselves to be pushed) into other forms of practice such as small-firm or in-house work. "Bou-

17. See sources cited supra note 10 .

An anthropologist who has studied the legal administration of a Texas family fortune finds a similar shift from an entrepreneurial mode of law practice to a defensive, wealth-conserving mode. Marcus, Law in the Development of Dynastic Families Among American Business Elites: The Domestication of Capital and the Capitalization of Family, 14 LAW \& Soc'Y REv. 859 (1980).

18. Compare listing for Wilson, Sonsini, Goodrich \& Rosati in Martindale-Hubbell Law DrRectory (1980) with the firm's listing in Martindale-Hubbell Law Directory (1989). 
tique" firms are beginning to appear, looking for niches in the market, and contracting for fragments of legal business. Litigation practice is on the rise. ${ }^{19}$

One useful way to track a number of these shifts is through study of the work of corporate general counsels' offices. These men and women have the major voice in deciding what legal services their companies will buy and from whom..$^{20}$ Not surprisingly, house counsel staffs have grown in numbers and specialization with their companies: Hewlett-Packard had thirty-four lawyers in 1982, and has forty-seven now. ${ }^{21}$ The pattern of jobs these lawyers do varies widely: Some (often, these days, JD-MBA's with a preference for mixing business with legal work) displace outside lawyers as repositories of general business advice and become important senior managers, playing a broad executive role in which legal affairs are only one among several resposibilities; others are hired simply for cost-cutting reasons, to perform routine legal tasks (drafting and reviewing contracts, handling employee complaints) more cheaply than outside lawyers can. Other inhouse lawyers are specialists. A high-technology company is likely first to hire a general counsel. When a second lawyer is added, he or she is often a patent lawyer, whose work will consist chiefly of developing and filing patent applications, though later this lawyer may draft confidentiality agreements, review scientific papers before publication to ward off issues of intellectual-property law, and supervise litigation related to patents. Outside the patent area, few in-house specialties are consistent across companies: Whether company lawyers primarily do contract, labor, tax, or securities work seems largely to depend on their prior experience in the outside firms from whom virtually all in-house lawyers are recruited. The larger companies, besides adding specialists in substantive legal areas, assign general lawyers to specific product lines and regions of the country.

The growth in size and responsibilities of these in-house staffs is clearly beginning-though only just beginning-to affect the structure of outside practice. It is still the custom that a company will lean primarily on a single law firm, ${ }^{22}$ with which it develops a longstanding relationship, and which does all or most of its legal business. These relationships sometimes grow out of personal and business connections between company founders and their first lawyers; the lawyer often cements the relationship by serving on the board of directors. Sometimes the general counsel of the company simply retains his ties to the firm where he used to work. But the old

19. See generally Symposium on the Corporate Law Firm, 37 STAN. L. REv. 271 (1985) (on the national trend).

20. The following account of in-house practices is based upon information drawn from interviews of 20 in-house lawyers for high-technology companies in the summer of 1988.

21. Interview with Marcia Adams, Senior Attorney, Hewlett-Packard Corp..

22. Or rather, two firms-one for patent business and the other for everything else. 
arrangements are beginning to erode. Most in-house lawyers we interviewed reported a gradual shift of work from primary outside counsel to a multifirm system, often using smaller "boutique" firms that specialize in tax, international, labor, immigration, benefits, or real estate law, either because the primary firm had become too costly, or did not give enough partnerlevel attention to the client, or because it could not service the specialty. Corporate cost-consciousness, in addition to pulling many legal jobs inside the company, has shifted authority to buy legal services from top management to functional departments less concerned with maintaining personal ties with outside lawyers and more with balancing cost and quality of service and keeping control over services performed.

In-house counsel have all developed techniques to monitor the quality and control the cost of outside work. Some of these are quite stringent: detailed and regular accounting of all bills, refusal to pay unacceptable items, negotiated fee discounts, detailed specification of the amount and type of the work to be done and of the particular partners and associates to perform it, and transferring of business, after unsatisfactory experiences, to a different firm, or to inside lawyers. Similarly, all of them keep close control over major litigation-reviewing all filings in draft form, holding strategy conferences with outside counsel, and managing costs through budget ceilings or by insistence on detailed itemization of bills. Inside lawyers also participate more and more in major lawsuits-conducting depositions, preparing witnesses, and reviewing documents during discovery-though the prevailing pattern is still to delegate this work to the outside firm.

The emerging trend in the Valley, then, seems quite similar to those that have already overtaken major businesses and their lawyers in big-city practice: a gradual shift away from the single outside provider to the spreading of specialized transactions among outside firms, and a gradual shift of some legal work, and especially of authority to control the terms and costs of legal work, away from outside firms into corporate staffs. The conventional wisdom, in the past, was that house counsel work was less independent, less "professional" than practice in law firms. But most of the in-house lawyers we talked to expressed a great deal of satisfaction with their work, and spoke of it as more independent and professional than the outside-firm jobs they had left. This view had much to do with their relative freedom from the detailed monitoring, supervision, and time and cost accounting that outside lawyers must now endure, as associates dance to the tune of the partners, and partners dance to the tune of their clients.

\section{CONCLUSION}

All sorts of assertions are commonly made about the relation of lawyers to industrial change. Lawyers are often said to be either indispensable to 
entrepreneurship or a wasteful drag on it. These assertions are completely untested, and necessarily so. From a research standpoint, the underlying questions are tough and intractable. For one thing, there is not and cannot be anything even remotely resembling a control group. There is no way to examine what America would be like if, everything else remaining the same, lawyers disappeared off the face of the earth. This might make an interesting thought experiment, but not much more. Nor does salvation lie in "natural" or quasi-experiments. Underlawyered Japan is thrown up as just such a happy instance-a major industrial power without hordes of lawyers. But again there are so many obvious differences between the two societies that it would be presumptuous to claim much from the comparison of numbers of lawyers, or from differences in modes of lawyering, in the two countries. The Japanese experience is no doubt full of interesting lessons, but it has to be approached with extreme caution..$^{23}$ But even if the global question is intractable, it might be possible to examine particular industries or states of the economy, at particular times. To find out what is happening to law practice in a single regional economy dominated by high-technology firms would be a modest start, at best, on such a project.

23. For skeptical views concerning the alleged Japanese comparative advantage in lower levels of legalism and litigiousness, see F. UPHAM, LAW AND SOCLAL CHANGE IN POSTWAR JAPAN (1987); J.M. Ramseyer, The Costs of the Consensual Myth: Antitrust Enforcement and Institutional Barriers to Litigation in Japan, 94 YALE L.J. 604 (1985). 
. 